\title{
Human Cruelty and Love to Animals
}

\author{
M Ashraful Kabir \\ Lecturer in Zoology, Cantonment Public School and College, District- Nilphamari, Bangladesh \\ ashraful_wb@yahoo.com
}

\begin{abstract}
This paper is based on aquarium fishes (various types $1=2.86 \%$ ), poultry (field pigeon, fancy pigeon, Eurasian collared dove, deshi fowl, cobb=broiler, ISA brown, domesticated turkey, guineafowl, domestic duck, muscovy duck, goose, Japanese quail (12=34.29\%), animal husbandry (deshi cow, BBG=Black Bengal Goat, jamnapari, buffalo, sheep, pig, Bangladeshi horse, Indian horse, Bhutani horse, rabbit, guinea pig, albino rat, deshi dog, foreign dog, deshi cat, foreign cat $(16=45.71 \%)$, cage birds (macaw, alexandrine parakeet, cockatoo, budgerigar, lovebird, java sparrow $(6=17.14 \%)$. Higher love was found in (16 animals) aquarium fishes, Eurasian collared dove, domesticated Turkey, guineafowl, muscovy duck, cockatoo, lovebird, budgerigar, macaw, alexandrine parakeet, java sparrow, black bengal goat, jamnapari, foreign dog, deshi cat and foreign cat and cruelty higher in (13 animals) field pigeon, fancy pigeon, deshi fowl, Japanese quail, deshi cow, buffalo, pig, Bangladeshi horse, Indian horse, rabbit, guinea pig, albino rat and deshi dog and finally cruelty and love both were same (6 animals) in cobb fowl, ISA fowl, domestic duck, goose, sheep and Bhutani horse. Out of 35 animals the result suggested that huge cruelty were found in pig (87.5\%) and the lowest in foreign dogs and cats (0\%). So, huge love on foreign dogs and cats (100\%) and lower love on pig (12.5\%) (Table 1; Diagram 1). In case of cage birds for talking ability it is reared with huge love but mostly reared in small or medium sized cages which are not fits with animal law. Caponizing in birds and castration in bovine group and horse was common. Torturing on animals in circus was common. Due to get huge meat caponizing in fowls and castration in bovine animals were remarkable. Once upon a time hunting of guest birds in winter season was very common but now due to wildlife act these incidents sudden happen. Though we need to slaughter animals for protein but this is drastically higher than our demand. Sometimes, due to superstitions some animals' especially garden lizards are caught by people and killed.
\end{abstract}

Keywords: Animals; Caponize; Castration; Domestic; Odd; Pet; Wildlife.

\section{INTRODUCTION}

There are a lot of human hobbies of the world. Some people are expert on some creative writing. Some are fond of reading books or articles which are the initiator of their topic to thinks many things. Taxidermy is the great art to preserve the dead body of the animals as a living one which is the tools for study the history of organism. Animal collection, birdwatching and hunting are the points to understand something. Animal fancy as well as fancy pigeons were the great hobby of many renowned persons of the world and now this is converted into pigeon racing in many countries as well as in Bangladesh. Tumbler and roller pigeons performs somersaults in the sky was a great enjoyment in mughal history. World kennel society and horse racing is the great show of the world of many countries. Unusual pet animals are such animals which are uncommon or rare as pets. On the other hand the odd means strange or peculiar animals which shows unusual behaviour to human. In Bangladesh unusual pet animals are cobra, python, other snakes, stray dogs, rat, jackal and mongoose. In other parts of the world those are pig, hedgehog, cougar, piranha, snakes, crab, scorpion and spider. Cruelty to animals also called animal abuse or animal neglect. Moreover, it can be harm such as killing for food or fur with respect to slaughter. Focus on the animals in human mainly for food, cloth, entertainment and research. Before establishing the modern biology the similarities between human and other animals considered complete distinction from those animals. Rene Descartes thought that nonhumans with no soul and mind (Mary 1999). Close analysis shows that human features such as language, tools use and self-consciousness can be found in some animals (David 2007). Darwin believed that human beings have a direct kinship with other animals with social, mental and moral lives too. He also mentioned in that there is no fundamental difference between man and the higher mammals in their mental faculties (Darwin 1871). Peter Singer and Tom Regan have argued that because animals have the ability to feel pain as human, their suffering should be given equal consideration. In one survey, $68 \%$ of the public thinks that low meat prices are more important than 
the well being of farm animals (Norwood and Lusk 2010). Animal cruelty is in two categories- active and passive. Lack of action rather than the action itself this is passive cruelty and examples are starvation, dehydration, parasite infestations, animals skin and inadequate medical care. A number of animals used in labs, fur industry, race, zoos and circuses (Gaverick and Cheryl 2007). 'American Society for the Prevention of Cruelty to Animals' reported that chicken, cow, pig and other animals are subjected to cruelty because male fowls don't lay eggs. Due to caging method of laying hens it showed osteoporosis (Gaverick and Cheryl 2007). To reduce aggression in pigs after birth the piglets are castrated, tails are amputated, and their teeth clipped (David 2007). Active cruelty is flushing a live aquarium fish thrown into the toilet (Jamie 2013; Kelli 2013). 13\% of intentional animal abuse cases involve domestic violence, $71 \%$ women have reported that their partner hurt or killed their pets; $32 \%$ of these women reported that their children killed pets (American Humane Association 2006). A survey on some psychiatric patients who showed repeatedly tortured to dogs and cats at high levels. Animals' cruelty is found in the south Korean film 'The Isle' (McKeague 2006). In circus animal trainers have argued that harm caused by the use of whips, chains or training implements (Patton 2007). In 2009, Bolivia passed legislation banning the use of any animals in circuses either it is wild or domestic. Some circuses now present animal-free acts. In case of fancy pigeons rearing a suitable loft is the first requirement. The system you rear those fancy pigeons will not get any troubles when you are getting full enjoyment with pigeons (Amendment Ordinance 69, Section 1). In Bangladesh perspective the Wildlife Act is indirectly related with domestic animals which deals or explain the dealer who not allowed transport or sell wild animals, trophies or meat, purchase, preserve, killing, poisoning, trapping, injury, nest destroy and egg collection. No person shall import any live wild animal (second schedule) and not allowed for exporting those animals (first schedule) (Bangladesh Wildlife Act, 1974).

\section{MATERials AND MethodS}

Aquarium fishes were kept in most restaurants and residences. Animal husbandry of Bangladesh is very common in semirural and rural areas where huge birds and mammals were common. In pet shop of Bangladesh sells many exotic parrots and parakeets for its talking ability and sparrow which chirping is more enjoyable. Foreign dogs and cats were available in Dhaka as luxurious pet which deals kennel and cat association and finally our common and number one mammalian pest rats and mice are killed by poison or trap and this is a common cruelty on it.

\section{RESUlts}

\subsection{Birdlife within Cage}

In many of our local or indigenous birds like tailorbird, bee-eater, hill myna, rose-ringed parakeet, blossom-headed parakeet, Chinese spotted dove, white-breasted waterhen, purple moorhen, bank myna, pied myna, common myna, munia, whiskered bulbul etc a lot of cage birds which shows ultimate die within cage due to cruelty. It can't get proper maintenance and food. Due to talking ability rose-ringed parakeet and hill myna is reared for love attitude but narrower space within cage and excess pressure on it for talking practice and mismanagement or diseases it die. Single birds rearing in that case either it is male or female there causes reproductive barrier. After passing a long time within cage and if it's being release not copes with the natural state. So, it's easily caught by other predator birds like crow and falcon.

\subsection{Castration}

In Bangladesh this is a common phenomenon. In cows males are castrated due to ploughing in the field. Goats are used just for soft meat. Sheep castration is not very common in its herd. Buffalo is being castrated by the use of castration machine (burdizzo). This is one of the easiest ways where animals get less pain. Due to uses in land for cultivating and carrying goods this castration helps. In case of male horse castration occurs at the mid ages for protecting it unpleasant behavior. The fog of the teak trees' secretion/glue is used for early healing of horses' testis. Pig castration also found due to getting huge meat. Cocks are castrated for getting double flesh than noncastrated fowl. When cock reaches at four months is ready to caponize. Some peoples in Bangladesh make castration in dogs only for master's house protection and this dog not mix with other dogs or female. Peoples who are engaged themselves to do this castration of the animals use very simple open method. Just cut the scrotal sac by sharp blade or knife and then remove both testes from the scrotum. For caponizing in cock surgical ligature which is normal cloth thread is used between the cut portion of keel bone and 
cloaca. Turmeric and mustard oil is used for early healing with germ-free environment and fly-borne diseases. When any vet is performed this act they use antibiotic powder sterilize the pointed area by rubbing disinfectants and sometimes they use other medicines if required (Table 1).

Table1. Showing Mainly the Rate of Cruelty and Love

\begin{tabular}{|c|c|c|c|c|}
\hline Animals & Cruelty & Love & $\begin{array}{l}\text { Cruelty } \\
(\%)\end{array}$ & $\begin{array}{l}\text { Love } \\
(\%)\end{array}$ \\
\hline $\begin{array}{l}\text { aquarium } \\
\text { fishes }\end{array}$ & $\begin{array}{l}\text { less feed/bad feed, congested } \\
\text { space }\end{array}$ & $\begin{array}{l}\text { original affection, conscious, } \\
\text { enjoy }\end{array}$ & 40 & 60 \\
\hline field pigeon & $\begin{array}{l}\text { slaughter, killing, less feed/bad } \\
\text { feed, congested space, dirty place, } \\
\text { lab animal, not proper treatment }\end{array}$ & original affection, enjoy & 77.78 & 22.22 \\
\hline fancy pigeon & $\begin{array}{l}\text { less feed/bad feed, congested } \\
\text { space, bad loft, dirty place, not } \\
\text { being exercise, bad collection, not } \\
\text { proper treatment, non-scientific } \\
\text { farming }\end{array}$ & $\begin{array}{l}\text { original affection, for huge } \\
\text { output, conscious, enjoy }\end{array}$ & 66.67 & 33.33 \\
\hline $\begin{array}{l}\text { eurasian } \\
\text { collared dove }\end{array}$ & non-scientific farming & $\begin{array}{l}\text { original affection, for huge } \\
\text { output, conscious }\end{array}$ & 25 & 75 \\
\hline deshi fowl & slaughter, castration/caponize & output & 66.67 & 33.33 \\
\hline cobb fowl & slaughter, dirty place & for huge output, conscious & 50 & 50 \\
\hline isa fowl & slaughter, dirty place & for huge output, conscious & 50 & 50 \\
\hline $\begin{array}{l}\text { domesticated } \\
\text { turkey }\end{array}$ & slaughter & $\begin{array}{l}\text { original affection, conscious, } \\
\text { enjoy/output }\end{array}$ & 25 & 75 \\
\hline guineafowl & non-scientific farming & $\begin{array}{l}\text { original affection, conscious, } \\
\text { enjoy/output }\end{array}$ & 25 & 75 \\
\hline $\begin{array}{l}\text { domestic } \\
\text { duck }\end{array}$ & $\begin{array}{l}\begin{array}{l}\text { slaughter, dirty } \\
\text { scientific farming }\end{array} \\
\end{array}$ & output, conscious, enjoy/output & 50 & 50 \\
\hline $\begin{array}{l}\text { muscovy } \\
\text { duck }\end{array}$ & slaughter, non-scientific farming & $\begin{array}{l}\begin{array}{l}\text { original affection, } \\
\text { conscious, enjoy/output }\end{array} \\
\end{array}$ & 33.33 & 66.67 \\
\hline goose & slaughter, non-scientific farming & $\begin{array}{l}\begin{array}{l}\text { original affection, } \\
\text { conscious, enjoy/output }\end{array} \\
\end{array}$ & 50 & 50 \\
\hline cockatoo & talking $\mathrm{p}$ & $\begin{array}{l}\text { original affection, conscious, } \\
\text { enjoy/output }\end{array}$ & 25 & 75 \\
\hline lovebird & non-scientific farming & $\begin{array}{l}\text { original affection, output, } \\
\text { conscious, enjoy/output }\end{array}$ & 20 & 80 \\
\hline budgerigar & $\begin{array}{l}\text { talking practice, non-scientific } \\
\text { farming }\end{array}$ & $\begin{array}{l}\text { original affection, output, } \\
\text { conscious enjoy/output }\end{array}$ & 40 & 60 \\
\hline macaw & $\begin{array}{l}\text { congested space, not being } \\
\text { exercise, non-scientific farming }\end{array}$ & $\begin{array}{ll}\begin{array}{l}\text { original affection, } \\
\text { conscious, enjoy/output }\end{array} & \text { output, } \\
\end{array}$ & 42.86 & 57.14 \\
\hline $\begin{array}{l}\text { alexandrine } \\
\text { parakeet }\end{array}$ & $\begin{array}{l}\text { congested space, not being } \\
\text { exercise, non-scientific farming }\end{array}$ & $\begin{array}{ll}\begin{array}{l}\text { original affection, } \\
\text { conscious, enjoy/output }\end{array} & \text { output, } \\
\end{array}$ & 42.86 & 57.14 \\
\hline japanese quail & $\begin{array}{l}\text { slaughter, congested space, bad } \\
\text { loft, dirty place, not being } \\
\text { exercise, non-scientific farming }\end{array}$ & output, enjoy/output & 75 & 25 \\
\hline java sparrow & non-scientific farming & $\begin{array}{l}\text { original affection, conscious, } \\
\text { enjoy/output }\end{array}$ & 25 & 75 \\
\hline deshi cow & $\begin{array}{ll}\text { slaughter, dirty } & \text { place, } \\
\text { castration/caponize, vehicle, goods } \\
\text { loading, beating }\end{array}$ & $\begin{array}{l}\text { original affection, for huge } \\
\text { output, conscious }\end{array}$ & 66.67 & 33.33 \\
\hline $\begin{array}{l}\text { bbg (black } \\
\text { bengal goat) }\end{array}$ & slaughter, castration/caponize & $\begin{array}{l}\text { original affection, for huge } \\
\text { output, conscious }\end{array}$ & 40 & 60 \\
\hline $\begin{array}{l}\text { jamnapari } \\
\text { goat }\end{array}$ & slaughter, castration/caponize & $\begin{array}{l}\text { original affection, for huge } \\
\text { output, conscious, enjoy/output }\end{array}$ & 33.33 & 66.67 \\
\hline buffalo & $\begin{array}{l}\text { slaughter, dirty } \\
\text { castration/caponize, vehicle, goods } \\
\text { loading }\end{array}$ & output, conscious & 71.43 & 28.57 \\
\hline sheep & slaughter, castration/caponize & output, conscious & 50 & 50 \\
\hline pig & $\begin{array}{l}\text { slaughter, killing, dirty place, } \\
\text { castration/caponize, beating, not } \\
\text { proper treatment, non-scientific }\end{array}$ & output & 87.5 & 12.5 \\
\hline
\end{tabular}




\begin{tabular}{|c|c|c|c|c|}
\hline & farming & & & \\
\hline $\begin{array}{l}\text { bangladeshi } \\
\text { horse }\end{array}$ & $\begin{array}{l}\text { castration/caponize, vehicle, goods } \\
\text { loading, riding, racing }\end{array}$ & $\begin{array}{l}\text { original affection, output, } \\
\text { conscious, enjoy/output }\end{array}$ & 55.56 & 44.44 \\
\hline indian horse & $\begin{array}{l}\text { castration/caponize, vehicle, goods } \\
\text { loading, riding, racing }\end{array}$ & $\begin{array}{l}\text { original affection, } \\
\text { conscious, enjoy/output }\end{array}$ & 55.56 & 44.44 \\
\hline bhutani horse & $\begin{array}{l}\text { castration/caponize, vehicle, goods } \\
\text { loading, riding }\end{array}$ & $\begin{array}{l}\begin{array}{l}\text { original affection, } \\
\text { conscious, enjoy/output }\end{array} \\
\end{array}$ & 50 & 50 \\
\hline rabbit & $\begin{array}{l}\text { slaughter, dirty place, not being } \\
\text { exercise, lab animal, not proper } \\
\text { treatment, non-scientific farming }\end{array}$ & $\begin{array}{l}\text { original affection, output, } \\
\text { conscious, enjoy/output }\end{array}$ & 60 & 40 \\
\hline guinea pig & $\begin{array}{l}\text { congested space, dirty place, not } \\
\text { being exercise, lab animal, not } \\
\text { proper treatment, non-scientific } \\
\text { farming }\end{array}$ & $\begin{array}{l}\text { original affection, conscious, } \\
\text { enjoy/output }\end{array}$ & 66.67 & 33.33 \\
\hline albino rat & $\begin{array}{l}\text { congested space, bad loft, dirty } \\
\text { place, not being exercise, lab } \\
\text { animal, not proper treatment, non- } \\
\text { scientific farming }\end{array}$ & $\begin{array}{l}\text { original affection, output, } \\
\text { conscious, enjoy/output }\end{array}$ & 63.64 & 36.36 \\
\hline deshi dog & $\begin{array}{l}\text { killing, less feed/bad feed, dirty } \\
\text { place, } \\
\text { amputation, beating, not proper } \\
\text { treatment, irritation }\end{array}$ & $\begin{array}{l}\text { original affection, conscious, } \\
\text { enjoy/output }\end{array}$ & 72.73 & 27.27 \\
\hline foreign dog & not found & $\begin{array}{l}\text { original affection, conscious, } \\
\text { enjoy/output }\end{array}$ & 0 & 100 \\
\hline deshi cat & dirty place & $\begin{array}{l}\text { original affection, conscious, } \\
\text { enjoy/output }\end{array}$ & 25 & 75 \\
\hline foreign cat & not found & $\begin{array}{l}\text { original affection, conscious, } \\
\text { enjoy/output }\end{array}$ & 0 & 100 \\
\hline
\end{tabular}

\subsection{Trapping/Hunting/Poisoning}

Once upon a time in Bangladesh hunting was common. Now this act has reduced due to establish a strong wildlife law or consciousness in people. Doves are caught by another trained dove which always makes sound. Dove is sold in pet shop for pet but it being slaughter as pigeons. White-breasted waterhen, purple moorhen, pond heron are trapped and it is sold for meat. Not only our native bird but also guest or migratory birds are being trapped by poacher and sells in open market for meat. This is a great cruelty to them. Rats in villages are commonly trapped or poisoned by people and die.

\subsection{Irritating}

Irritation to the street dogs in Bangladesh is mostly common. During the breeding season in front of the highway or any occasional party it always irritated by people especially children. When in sleep some children thrown hot or water on its body. Ultimately in run away or bite the victim. Moreover, dog carries rabies virus. Cats are normally not serious than dog. It is being reared as hobby in human residences. Dog and cat pet organization of Bangladesh is not bad as well.

\subsection{Animal Transportation}

Hanging of the fowls and ducks on bicycle this scenario is common in Bangladesh. Pigeons are transported in banana barks hole which make huge temperature and it happens death of pigeons squab. Only fancy pigeons are carried by nice and large spaced cage.

\subsection{Circus Animals}

A research on circus animals of Bangladesh suggested that 7 horses, 4 bears and several spitz dogs are died due to dysentery and colic pain. Illegal animal poacher, hunter, tribal people and snake charmers are involved to sell these animals to the circus team. Most of the animals in circuses are male. All animals are reared in small cages and unhygienic environment is very common. While animal training session the trainer used whip and hook to control those animals. For supplying bad or dirty food the animals often sick and suffer by malnutrition. If we deduct the animal portion from the circus it will be better for animals and mankind also (Kabir 2013). Great elephant trainer Axel Gautier was killed by elephant in Florida in 5 May 1993 (incident (s), lawsuit filed). In circus performing for handling the animals there possibilities to attack by them especially elephant, Arabian horse, donkey and bear 
(updated, 2001). During the training schedule for the animals this is a cruel training method (The Proposed Wildlife Act). According CITES, both Asian and African elephant is banned from the circus from 1990 (updated, 2001).

\subsection{Superstitional Animals}

The practice of traditional medicine in Bangladesh is an integral part of our culture which is essential for recovering some diseases (Qureshi 1984). 75-80\% village dwellers profession is farming and their income is based on agriculture (Ghani 1990). Traditional medical practice is guided by their culture and life style on the use of plant and animal parts (Animal Nutrition Section, 2005-2006; Sofowora 1982). Drinking of cows' urine which relief fever and cancer. Human urine is used for healing the wounds. Pigeon blood has a strong effect for paralysis by massage on the body. For early puberty collared doves' flesh can be use. Pimples over the body or on face the molluscan shell could repair (Mahawar and Jaroli 2006). In underdeveloped or developing countries animals' superstition is very common. From the very beginning of human ancestry they used animals' skin, teeth, fur, blood and flesh for the various diseases. After the scientific discovery all sorts of superstitions are decreasing day by day. Mainly rickshawpuller, addicted people, illiterate people and obsolete people takes this medicine. By this tradition we are loosing our biodiversity. For any localize pain the oil of jackal, spiny-tailed lizard and Chinese leech are commonly used. Superstitional medicines are used in human psychological, astrological, sexual and respiratory related. If we protect such animal concerning bogus traditions we could restore some wild animals in nature. We should study the cultural anthropology to solve this problem in our society. Some little educated and low income people believe this tradition and take those animals parts as medicine. In case of animals mostly they use skin and bones (Kabir 2014).

\subsection{Aquarium Animals}

Aquarium is a common ornamental tool in house. In luxurious family it looks nice. Some people just keep a small aquarium where very few oxygen for the fishes. This is a cruelty also. Small sized aquarium not posses an aerator this is a death place of fishes. Moreover, people not clean the wall of aquarium ultimately the fungus is grown which are the cause of diseases of fishes, snakes and terrapins. If it is possible to maintain natural environment of such animals it will be good for them and not focuses as cruelty.

\subsection{Slaughtering}

Animal slaughtering is very common in broadly poultry and bovine for great source of protein. Moreover, if any animals are diseased then it slaughtered for human meat. Euthanasia (peaceful death) could apply as less pain in this regard.

\subsection{Odd Pet Animals}

Sometimes people rear such type of animals which are really dangerous to human. Cougar, tiger, lion all are ferocious and may attack anytime. In circus performing these attacks are common. There are huge peoples who get fear to see snakes and dog. These are of course odd animal in our country. Acceptable, very cute, talking birds, very tame and calm and non carnivorous animals could be an ideal pet animal. We should avoid those odd animals in our living place. In our residence yard we can establish a mini zoo by allowing the concerned authority.

\section{DiSCUSSION}

All pigeons are totally confined and passing those days with a lot of pangs. In residential lofts are very congested and not posses fresh air so diseases mainly pox is common in such places. Some rearers have just hobby for buying pigeons but care is very poor. Feather cutting or taping is a common phenomenon though it is in captivity. Ultimately pigeons die and loss its breeding capability. Animal dealers are not well known on animal rights. Most vulnerable situation is that cleaning, mismanagement and less nutritious feeding. Common tendency of most rearers is that they are not conscious to their animals. The farmers not clean their animal houses regularly and due to lack or proper knowledge on breeding they make inbreeding depression. For unknowing they can't get pure animals ethics and jurisdiction to them was invisible. Some rearers only provide only 1-2 items for them which cause severe malnutrition. Huge artificial light is common but natural light and fresh air was few. Another observation was found that the rearers not get feed to animals in a specific time. 


\section{Ashraful Kabir}

Irregular feeding is one kind of torturing on those animals. Moreover, space per animal not scientific within the cages either in circus or pet in houses (Table 2 and 3). Egyptian law states that who inhumanely beats or kills any domesticated animal may be jailed or fined. The Criminal Code of South Sudan has laws against maltreatment of animals. Rides or overloads any animal which is old aged and sick shall be sentenced to imprisonment. In Chile they promote animal education in schools on animals. No person shall kill, injure, or cruelty to animals without due course as well as cattle, horses, goats, sheep, pigs, dogs, cats, pigeons, rabbits, chickens, and ducks in captivity in Japan. By European Union keeping egg laying hens bans in battery cage and declaw of cat. The Swiss animal protection laws are regulating the treatment of animals and exercise to dogs. In the London Police Act 1839, fighting or baiting lions, bears, badgers, cocks, dogs, or other animals were prohibited. It also prohibited owners from rabid dog bitten (Graham Robb 2007).

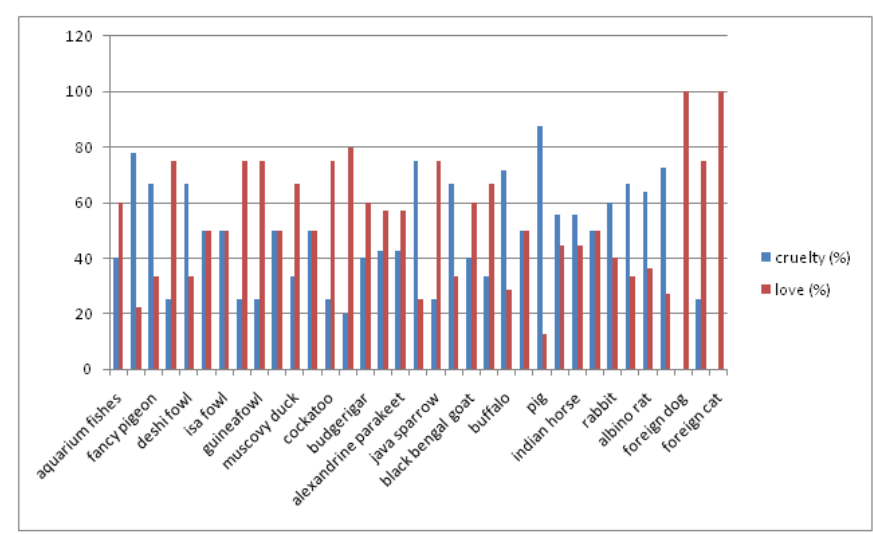

Figure1. Showing the Highest and Lowest Percentages of Cruelty and Love to Various Animals

Table2. Features of Cruelty and its Causes

\begin{tabular}{|l|l|}
\hline \multicolumn{1}{|c|}{ Features } & \\
\hline slaughter & human food \\
\hline killing & ferocious \\
\hline less feed/bad feed & economic \\
\hline congested space & economic/not known \\
\hline bad loft & economic \\
\hline dirty place & busy \\
\hline not being exercise & busy \\
\hline castration/caponize & reduce mating tendency/food \\
\hline vehicle & income \\
\hline goods loading & income \\
\hline riding & enjoy/economic \\
\hline racing & enjoy/economic \\
\hline lab animal & availability/relation to human/good result \\
\hline amputation & anger \\
\hline beating & protect themselves/enjoyment \\
\hline bad collection & not well known \\
\hline not proper treatment & only vitamin and common antibiotic/ignorance \\
\hline irritation & enjoy \\
\hline talking practice & enjoy \\
\hline non-scientific farming & not well known/not try to understand \\
\hline
\end{tabular}

Table3. Features of Love and its Causes

\begin{tabular}{|l|l|}
\hline \multicolumn{1}{|c|}{ Features } & \\
\hline completely pet & original affection \\
\hline huge feed/good feed & for huge output \\
\hline enough space & output \\
\hline good/expensive loft & output \\
\hline clean place & conscious \\
\hline being exercise & enjoy/output \\
\hline good collection & output \\
\hline proper treatment & output \\
\hline not irritation & original affection \\
\hline scientific farming & output \\
\hline
\end{tabular}




\section{CONCLUSION}

Cage birds were very common for its nice talking ability and it is reared in small cages. In winter season many poachers are caught migratory birds and finally it goes in our stomach as food. In circus some wild animals especially elephant and bear is common. Carnivorous bear when fight with human very serious injury may happen and elephant attack is worldwide common. Firstly domestication and then pet of some animals' cruelty or love has been shown. In human residences rats and mice are common mammalian pest which is killed by trap or poison bait. A lot of superstitions in animals' especially garden lizard are considered sucks human blood. So, it's killed by common people. Though horse were kept in good condition but sometimes it is castrated by people or use in vehicle and good loading. There are some aquariums which are not clean timely and aerator is very poor. Some ferocious animals such as python, cobra, dogs and mongooses are reared by snake charmer or common people which are not commonly allowed by people and it being considered as odd animals. Due to consider the cruelty and love to animals we should think what the right place for preserving of those animals. Game reserve, wildlife sanctuary, safari park, mini zoo and rescue centre could be the best place for animals which guarantees its love by people and stop cruelty.

\section{ACKNOWLEDGEMENT}

Author is giving immense thanks to his favourite professor Late Dr. M. Abdul Mannan, Department of Zoology of Rajshahi University, Bangladesh who always initiated to write this uncommon topic to animals. This nice idea on animals is come by him. In this regard the author is mentioning all credits of this paper are completely goes to him.

\section{REFERENCES}

Animal nutrition section. 2005-2006. Dhaka Zoo Guide: www.dhakazoo.org Arignar Anna Zoological Park:http://en.wikipedia.org/wiki/Arignar_Anna_Zoological_Park

Bangladesh Wildlife (Preservation) (Amendment) Act, 1974. Government of the People's Republic of Bangladesh.

Circus and ride elephant incidents. See-incident; incidents; lawsuits filed; lawsuit file-child's family

City of Gem Lake, Ramsey County 2009. Summary of ordinance 110. White Bear Press. Minnesota, USA.

http://www.gemlakemn.org/ordinances/downloads/110\%20Keeping\%20of\%20Pigeons.pdf

Darwin CR. 1871. The Descent of Man. p. 34.

David NC. 2007. Bred Meat: The Cultural Foundation of the Factory Farm. Law and Contemporary Problems 70 (1): 59-87.

Facts About Animal Abuse \& Domestic Violence American Humane Association Accessed 12 November 2006

Gaverick M. and Cheryl L. 2007. Farm-Animal Welfare, Legislation, and Trade. Law and Contemporary Problems 70 (1): 325-358.

Ghani A. 1990. Traditional medicine. Jahangirnagar University, Savar, Dhaka, Bangladesh.

Graham Robb G. 2007. The discovery of France: a historical geography from the Revolution to the First World War. W. W. Norton \& Company. pp. 167. ISBN 978-0-39305973-1. Retrieved 15 December 2011.

Jamie S. 2013. Brooklyn man furious his roommate wanted to move out allegedly murdered her fish. New York Post.

Kabir MA. 2013. Circus tradition of Bangladesh and fate in its animals. South Pacific Journal of Pharma and Bio Science (1): 51-57.

Kabir MA. 2014. Superstitions and traditional uses of animal in Bangladesh. Standard Journal of Biological Sciences 1(1): 005-008.

Kelli G. 2013. Man Busted For Killing Fish \& Allergic To Exercise.

Mahawar MM and Jaroli DP. 2006. Animals and their products utilized as medicines by the inhabitants surrounding the Ranthambhore National Park, India. J. Ethnobiol. Ethnomed. 2:46. $11 \mathrm{pp}$.

Mary M. 1999. The New Statesman 


\section{Ashraful Kabir}

McKeague A. 2006. An Interview with Kim Ki-Duk and Suh Jung on The Isle at monstersand critics.com, May 11, 2005. Retrieved March 11, 2006.

Norwood FB. and Lusk JL. 2010. Direct versus indirect questioning: An application to the well-being of farm animals. Soc Indic Res 96 (3): 551-565. doi:10.1007/s11205-009-9492-z.

Patton K. 2007. Frequently Asked Questions: Do circus trainers/handlers abuse animals? lionden.com. Retrieved 2008-05-23.

The proposed wildlife act: anomalies persist.

Qureshi MS. 1984. Tribal culture in Bangladesh. Institute of Bangladesh Studies, Rajshahi University, Bangladesh.

Sofowora A. 1982. Medicinal plants and traditional medicine in Africa. John Wiley \& Sons Ltd., New York, USA.

Updated March 2001. Animals and people at the circus: accidents, attacks, animal abuse, and other incidents. The Human Society of the United States, 2100 L Street, NW, Washington DC. 